\title{
Characterization of Clay Minerals in Brown Forest Soil Profiles (Luvisols) of the Cserhát Mountains (North Hungary)
}

\author{
T. NÉMETH and P. SIPOS \\ Institute for Geochemical Research of the Hungarian Academy of Sciences, \\ Budapest
}

\section{Introduction}

The physico-chemical properties (structure, rheological properties, water retention etc.) of soils are greatly influenced by their clay mineral composition (SZEGI et al., 2004). Due to their adsorption capacity clay minerals play an important role in the distribution of trace elements within a soil profile. As the adsorption properties of clay minerals depend not only on the amount and main type of clays, but on characteristics like swelling and layer charge, a detailed investigation of clay minerals and their alteration processes are needed for trace element distribution studies. Pedogenic clay minerals form dynamic systems. Based on their alteration from one to another species, the direction of the weathering process is predictable (TERRITO et al., 2005).

In earlier works the distribution of trace metals $\mathrm{Cu}, \mathrm{Ni}, \mathrm{Pb}$ and $\mathrm{Zn}$ in brown forest soil profiles (Luvisols) was studied by chemical (SIPOS, 2003), sequential extraction (SIPOS, 2004) and complex adsorption-desorption methods (SIPOS et al., 2005 ) within the frame of a regional environmental geochemical research project of the Cserhát Mountains in North Hungary.

This paper presents the clay mineralogy findings of this study, including the characterization of clay minerals in four brown forest soil profiles developed on different bedrocks, but influenced by similar pedogenic processes (e.g. clay illuviation) and a suggestion on the possible genesis and evolution of clay minerals in Luvisols of the Cserhát Mountains.

\section{Materials and Methods}

The clay fraction $(<2 \mu \mathrm{m})$ of soil samples was separated by sedimentation in distilled water. Cation exchange capacity (CEC) values were determined by saturation with $\mathrm{Ba}^{2+}$, based on the modified Mehlich method (RÉDLYNÉ, 1988).

Correspondence to: TIBOR NÉMETH, Institute for Geochemical Research of the Hungarian Academy of Sciences, H-1112 Budapest, Budaörsi út 45. Hungary. E-mail: ntibi@geochem.hu 
X-ray diffraction (XRD) measurements were carried out using a Philips PW 1710 diffractometer with $\mathrm{CuK} \alpha$ radiation at $45 \mathrm{kV}$ and $35 \mathrm{~mA}$. Mineral composition of the bulk soil was determined on random-powdered samples by semi-quantitative phase analysis. Clay minerals were identified by XRD diagrams obtained from parallel-oriented specimens. The following diagnostic treatments were carried out for all of the samples: ethylene glycol solvation at $60{ }^{\circ} \mathrm{C}$ overnight, $\mathrm{Mg}$ saturation followed by glycerol solvation at $95^{\circ} \mathrm{C}$ overnight, $\mathrm{K}$ saturation, heating at 350 and $550{ }^{\circ} \mathrm{C}$ for 2 hours. The GREEN-Kelly (1953) test (Li saturation) was used to distinguish between montmorillonite and beidellite, as recommended by LIM and JACKSON (1986). The layer charge of smectite was determined by the alkylammonium method of LAGALY (1994).

For TEM and AEM analyses a few milligrams of metal-ion saturated sample was dispersed mechanically in ethanol and dropped onto $3 \mathrm{~mm}$ collodion-carbon coated gold grids. Morphological and structural observations by TEM and chemical analyses by AEM were performed with a Philips CM20 transmission electron microscope used at $200 \mathrm{kV}$ accelerating voltage and equipped with a Noran energy dispersive system (EDS).

Description of the soil profiles. - The studied forest soil profiles are from different sites of the Cserhát Mountains in near vicinity of each other. The area has a temperate subcontinental climate, with a mean annual temperature of $8.9^{\circ} \mathrm{C}$, a mean annual precipitation of 600-620 $\mathrm{mm}$, reaching $650 \mathrm{~mm}$ at higher topography (P09 profile). The profile names refer to those used by SIPOS (2004). Profile P09 is situated near to Karancslapujtö village in an oak-hornbeam forest on Oligocene carbonaceous siltstone bedrock dominated by chloritic clay mineralogy. Profile P131 has developed on a similar Miocene siltstone near Kisbárkány in a small oak forest. The parent rock of Profile P151 is a Miocene limestone, sandy limestone. The profile itself can be found in an oak forest $2 \mathrm{~km}$ north of Mátraverebély-Szentkút. Profile P161 has developed on Miocene pyroxene-phyric andesite and is located $2 \mathrm{~km}$ south of the village Alsótold in an oak forest.

The main chemical and physical properties of the studied soil samples are summarized in Table 1. Further and more detailed description of the topography, geology, pedology, and chemical composition of the profiles can be found in SIPOS (2004), and on brown forest soils in Hungary in general in STEFANOVITS (1971).

\section{Results and Discussion}

\section{Profile P09}

The mineral composition of the bulk soil is $60-80 \%$ quartz with decreasing amounts downward, $5-10 \%$ feldspar, $10 \%$ and $25 \%$ calcite in the $\mathrm{BC}$ and $\mathrm{C}$ horizons, respectively. The amount of phyllosilicate clay minerals reaches its maximum in the $\mathrm{B}$ horizon (15\%), elsewhere it is around $10 \%$.

XRD patterns of the clay fraction after the different diagnostic treatments are shown in Fig. 1. The greatest peak at $14.5 \AA$ shifted to $15.5 \AA ̊$ upon ethylene-glycol 
Table 1

Some physico-chemical characteristics of the studied brown forest soil profiles (Cserhát Mountains, North Hungary)

\begin{tabular}{|c|c|c|c|c|c|c|c|c|c|}
\hline \multirow{2}{*}{$\begin{array}{c}\text { Parent } \\
\text { rock }\end{array}$} & \multirow{2}{*}{$\begin{array}{l}\text { Genetic } \\
\text { horizon }\end{array}$} & \multirow{2}{*}{$\begin{array}{c}\text { Depth, } \\
\mathrm{cm}\end{array}$} & \multirow{2}{*}{$\begin{array}{l}\text { Munsell } \\
\text { color }\end{array}$} & \multirow{2}{*}{$\begin{array}{c}\mathrm{pH} \\
\left(\mathrm{H}_{2} \mathrm{O}\right)\end{array}$} & TOC & Clay & Carb & $\mathrm{Al}_{2} \mathrm{O}_{3}$ & $\mathrm{Fe}_{2} \mathrm{O}_{3}$ \\
\hline & & & & & \multicolumn{5}{|c|}{$\%$} \\
\hline \multicolumn{10}{|c|}{ Profile P09 } \\
\hline Silt- & A & $0-5$ & 10YR3/4 & 6.39 & 6.74 & 8 & & 12.33 & 4.66 \\
\hline stone & E & $5-15$ & 7.5YR5/8 & 5.66 & 0.92 & 12 & & 16.45 & 6.39 \\
\hline & B & $15-$ & 10YR5/8 & 6.85 & 0.39 & 11 & & 16.30 & 6.76 \\
\hline & $\mathrm{BC}$ & $45-$ & 10YR6/8 & 8.08 & & 9 & 10 & 13.72 & 5.03 \\
\hline & $\mathrm{C}$ & $55-$ & 2.5YR6/4 & 8.41 & & 7 & 25 & 10.09 & 3.40 \\
\hline \multicolumn{10}{|c|}{ Profile P131 } \\
\hline Silt- & A & $0-45$ & $10 Y R 4 / 2$ & 5.23 & 2.31 & 10 & & 10.87 & 3.31 \\
\hline stone & $\mathrm{E}$ & $45-$ & $2.5 \mathrm{YR} 5 / 2$ & 5.05 & 0.25 & 13 & & 14.03 & 5.57 \\
\hline & B & $60-$ & $7.5 \mathrm{YR} 5 / 2$ & 5.09 & 0.27 & 16 & & 14.87 & 6.59 \\
\hline & $\mathrm{C}$ & $150-$ & $2.5 \mathrm{YR} 6 / 2$ & 5.51 & 0.14 & 15 & & 15.07 & 6.39 \\
\hline \multicolumn{10}{|c|}{ Profile P151 } \\
\hline Lime- & A & $0-30$ & $10 \mathrm{YR} 3 / 3$ & 5.27 & 3.48 & 11 & & 13.15 & 4.84 \\
\hline stone & $\mathrm{E}$ & $30-$ & $7.5 \mathrm{YR} 4 / 4$ & 5.27 & 1.06 & 14 & & 14.72 & 5.77 \\
\hline & B & $40-$ & 10YR5/4 & 5.80 & 0.78 & 17 & & 15.47 & 6.14 \\
\hline & $\mathrm{C}$ & $100-$ & 10YR6/4 & 7.84 & & 9 & 50 & 10.40 & 3.09 \\
\hline \multicolumn{10}{|c|}{ Profile P161 } \\
\hline Andes- & A & $0-40$ & 10YR3/3 & 5.84 & 2.29 & 13 & & 12.05 & 5.10 \\
\hline ite & $\mathrm{E}$ & $40-$ & 7.5YR4/2 & 6.3 & 1.05 & 9 & & 13.98 & 5.86 \\
\hline & B & $60-$ & 10YR5/6 & 6.05 & 0.6 & 13 & & 15.83 & 7.44 \\
\hline & $\mathrm{C}$ & $130-$ & $2.5 \mathrm{YR} 5 / 4$ & 6.12 & 0.35 & 12 & & 15.05 & 7.38 \\
\hline
\end{tabular}

Remarks: $\mathrm{TOC}=$ total organic carbon, $\mathrm{Carb}=$ carbonate minerals, Clay = clay sized fraction

solvation in the A, E and B horizons. The degree of expansion is less in the $\mathrm{BC}$, and the least in the $\mathrm{C}$ horizon. When $\mathrm{Mg}$ saturated and glycerol solvated, the basal peak remained at $14.5 \AA$ in all cases, showing the vermiculitic character of this swelling clay mineral. Potassium saturation partly caused the full collapse of high charge vermiculite to $10 \AA$, and partly the partial collapse of the chloritic phase to $14.1-$ 13.6 A. The partial instability of the chlorite structure against heating at $550{ }^{\circ} \mathrm{C}$ refers to the presence of vermiculitic component, which is indicated by the appearance of the $12 \AA$ peak in the $\mathrm{A}, \mathrm{E}$ and $\mathrm{B}$ horizons. In deeper horizons this phase behaved like a chlorite and remained stable at $550{ }^{\circ} \mathrm{C}$ heat treatment. To sum up, two major clay mineral phases were distinguishable in the P09 profile: a vermiculite and a randomly interstratified chlorite/vermiculite (soil chlorite), where interstratification of the layers could be present along the $c$ axis and also lateral. The degree of structural collapse due to K saturation and heating of soil chlorite - similarly to the expansion capacity - increases upward in the profile. The chloritic character is the strongest in the $\mathrm{C}$ horizon, and the vermiculitic one in the A horizon. This suggests the gradual alteration of chlorite to vermiculite during the weathering processes. 

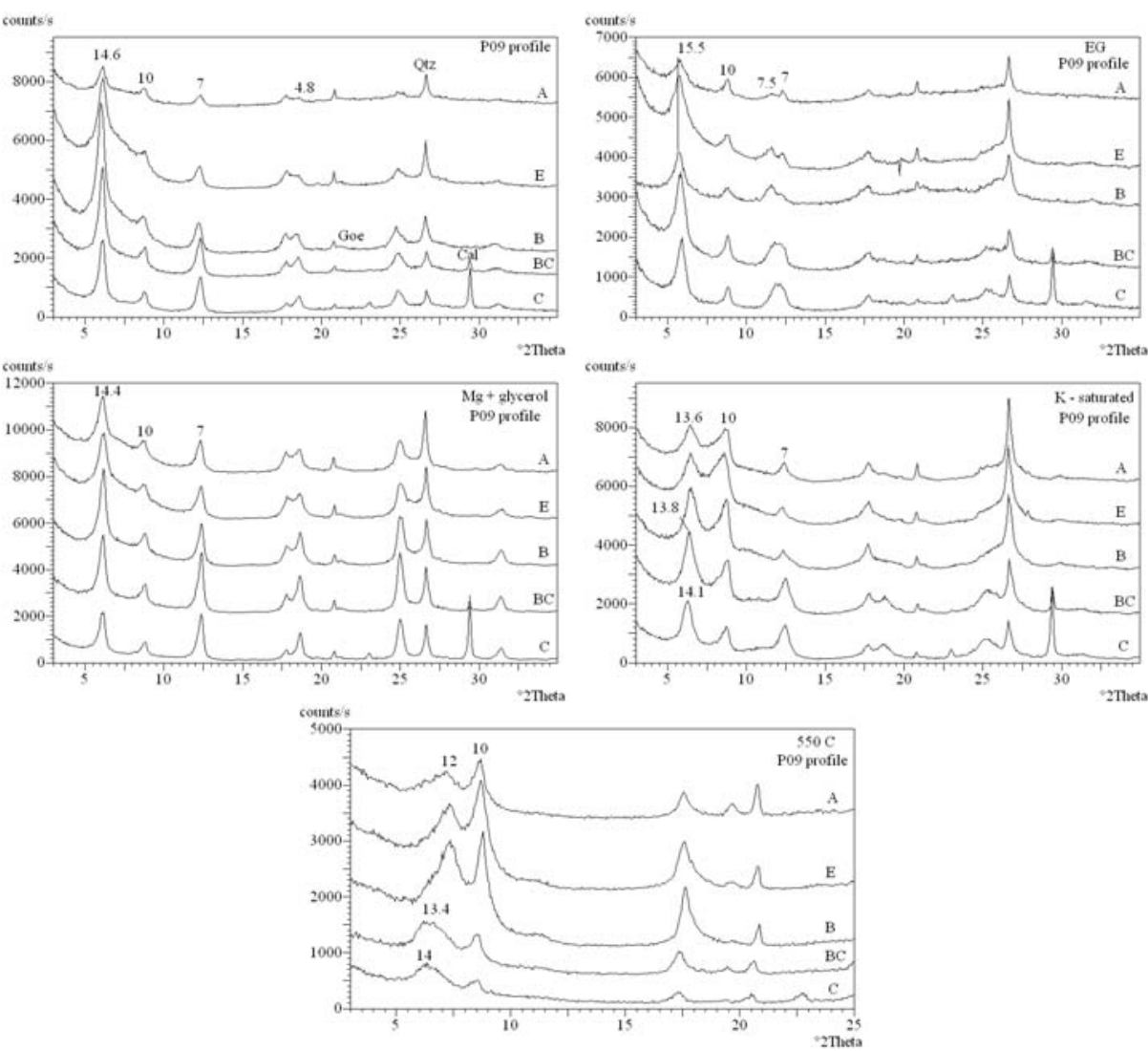

Fig. 1

XRD patterns of the clay fractions in the genetic horizons of Profile P09 after the diagnostic treatments. Remarks: Numbers indicate $\mathrm{d}$ values in $\mathrm{A} . \mathrm{Qtz}=$ quartz, $\mathrm{Cal}=$ calcite, Goe $=$ goethite

Based on the $1.50 \AA$ value of 060 reflections both vermiculite and soil chlorite are dioctahedral. Hydroxy-interlayered vermiculite is characteristic in fairly acidic $(\mathrm{pH}=4.9-5.4)$ forest soils in Hungary (SIMON et al., 2002). As the soil $\mathrm{pH}$ is higher (near to neutral), the presence of $\mathrm{OH}$-interlayered species - which exhibits similar $\mathrm{XRD}$ features - is improbable in the $\mathrm{P} 09$ profile.

The 10 Á reflection belongs to a minor amount of illite in the whole profile. In the clay fraction the highest proportion of illite is found in the A horizon.

Fig. 2 shows the TEM image of vermiculite in the $\mathrm{B}$ and chlorite in the $\mathrm{C}$ horizon. Chlorite forms larger $(0.5-1 \mu \mathrm{m}), 200 \mathrm{~nm}$ thick platy crystals, while vermiculite is thinner and smaller $(0.2-0.3 \mu \mathrm{m})$. Both vermiculite and chlorite have high iron contents $(6-10 \mathrm{wt} \%)$. TEM revealed the presence of goethite and other less crystallized iron-phases in the B horizon, which is in good agreement with the chemical data. 

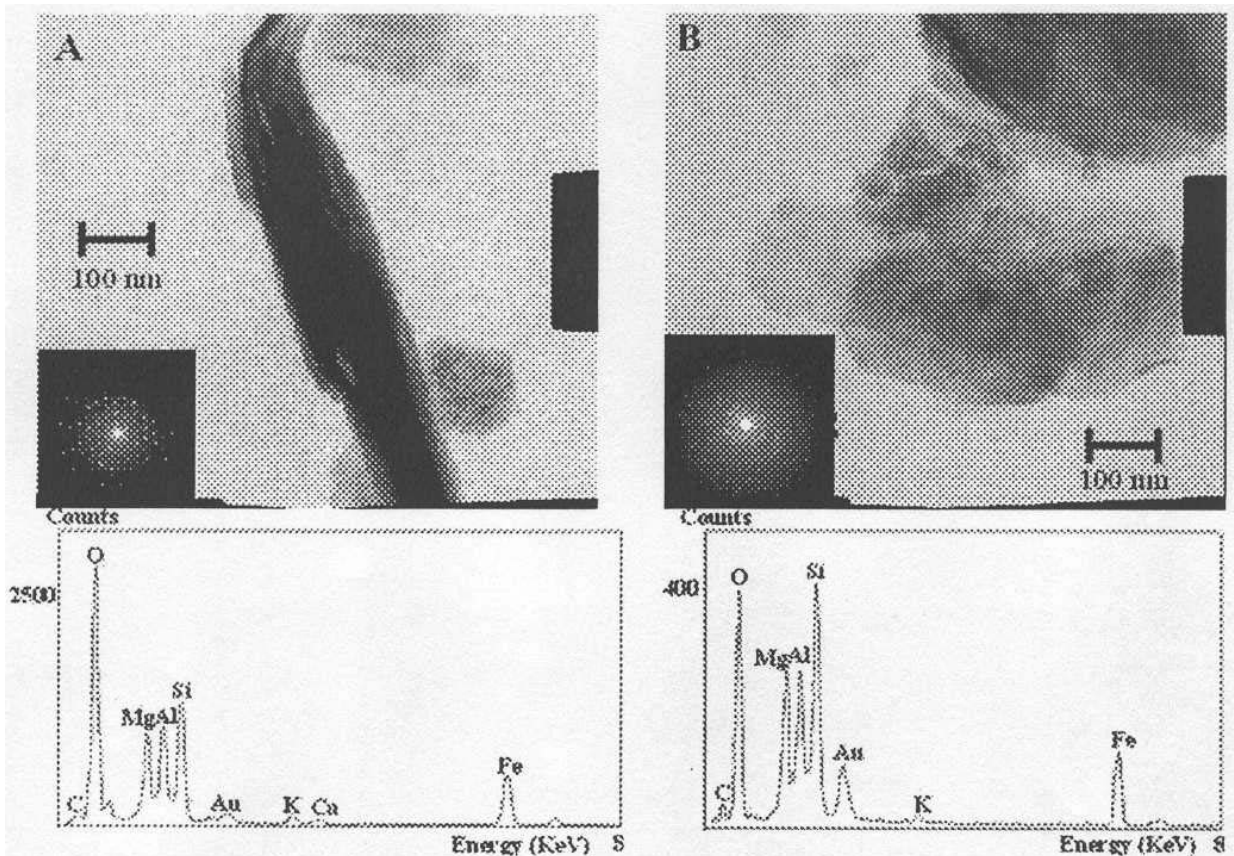

Fig. 2

TEM micrographs and referring TEM-EDS spectra of chlorite in the $\mathrm{C}$ horizon (A) and vermiculite in the B horizon (B) (Profile P09)

\section{Profile P131}

The bulk soil mineralogy is characterized by $40-70 \%$ quartz and $5-15 \%$ feldspars decreasing with depth. This profile has the highest clay mineral content, its quantity increases from 15 to $40 \%$ downward. Carbonate minerals are not present.

The predominating clay mineral in the whole profile is smectite, which swelled

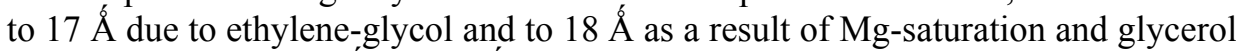
solvation (Fig. 3). $10 \AA \AA$ and $7 \AA$ reflections refer to minor amounts of illite and kaolinite, respectively. The proportion of these clay minerals is constant in the profile, and they are most likely inherited phases from the parent rock. K-saturation caused $12.5 \AA$ collapse of the smectite structure, indicating low layer charge. Increase of the $10 \AA$ peak in the upper horizons, however, suggests the presence of high charged smectite layers too. The heterogeneous layer charge distribution of smectite at $100 \mathrm{~cm}$ depth (top of the B horizon) is evidenced by alkyl-ammonium exchange (LAGALY et al., 1976). The layer charge ranges between 0.26 and 0.39 , with a mean of 0.325 charge per half unit cell. The CEC of the same clay fraction is $56 \mathrm{cmol} / \mathrm{kg}$. Based on $d_{060}=1.50 \AA$ the smectite is dioctahedral. After Li saturation and heating at $250{ }^{\circ} \mathrm{C}$ the smectite lost its expansion capacity, demonstrating the octahedral character of the layer charge, i.e. the smectite is montmorillonite. A small proportion of tetrahedral charge can be detected only in the $\mathrm{E}$ and $\mathrm{A}$ horizons, 

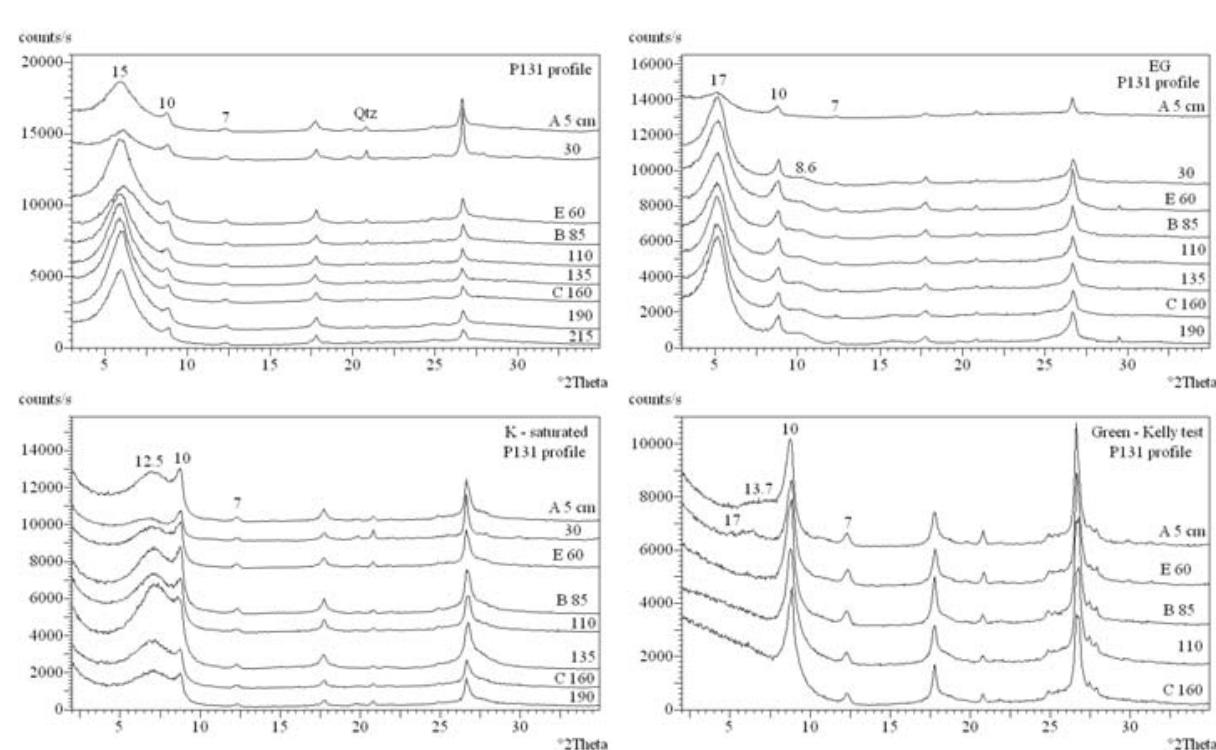

Fig. 3

XRD patterns of the clay fractions in the genetic horizons of Profile P131 after the diagnostic treatments

suggesting some conversion of octahedral to tetrahedral charge, which is in good agreement with the increase in the total layer charge in these horizons. Similar smectite alterations were described in clayey soils (i.e. Vertisols) (RIGHI et al., 1998; BADRAOUI \& BLOOM, 1990).

Based on TEM studies, the montmorillonite is found in the form of a few hundred nanometer-sized flakes. TEM-EDS analysis revealed a high amount of octahedral iron in the montmorillonite. Some percent of K suggests the interstratification of illite layers. In addition to smectite, the accumulation of iron in the B horizon is realized in pedogeneous Fe-oxides and hydroxides having the most various degree of crystallization: from amorphous phase, to goethite and to nano-sized idiomorphic hematite.

\section{Profile P151}

The amount of quartz in the $\mathrm{A}$ and $\mathrm{B}$ horizons is $50-70 \%$, whereas in the $\mathrm{C}$ horizon it is only $30 \%$, due to the very high calcite content (nearly $50 \%$ ). The quantity of feldspars is 20,15 and $5 \%$ in the $\mathrm{A}, \mathrm{B}$ and $\mathrm{C}$ horizons, respectively, showing a continuous decrease with depth. The $\mathrm{A}$ and $\mathrm{C}$ horizons contain clay minerals in a similar quantity $(10-15 \%)$, whereas their amount increases in the B horizon to $25 \%$.

The peaks at $7 \AA$ and $3.58 \AA$ are attributed to kaolinite, the quantity of which is relatively constant in the whole profile (Fig. 4). The basal peak of illite at $10 \AA$ is more striking in the ethylene-glycol solvated samples. The decreasing relative in- 

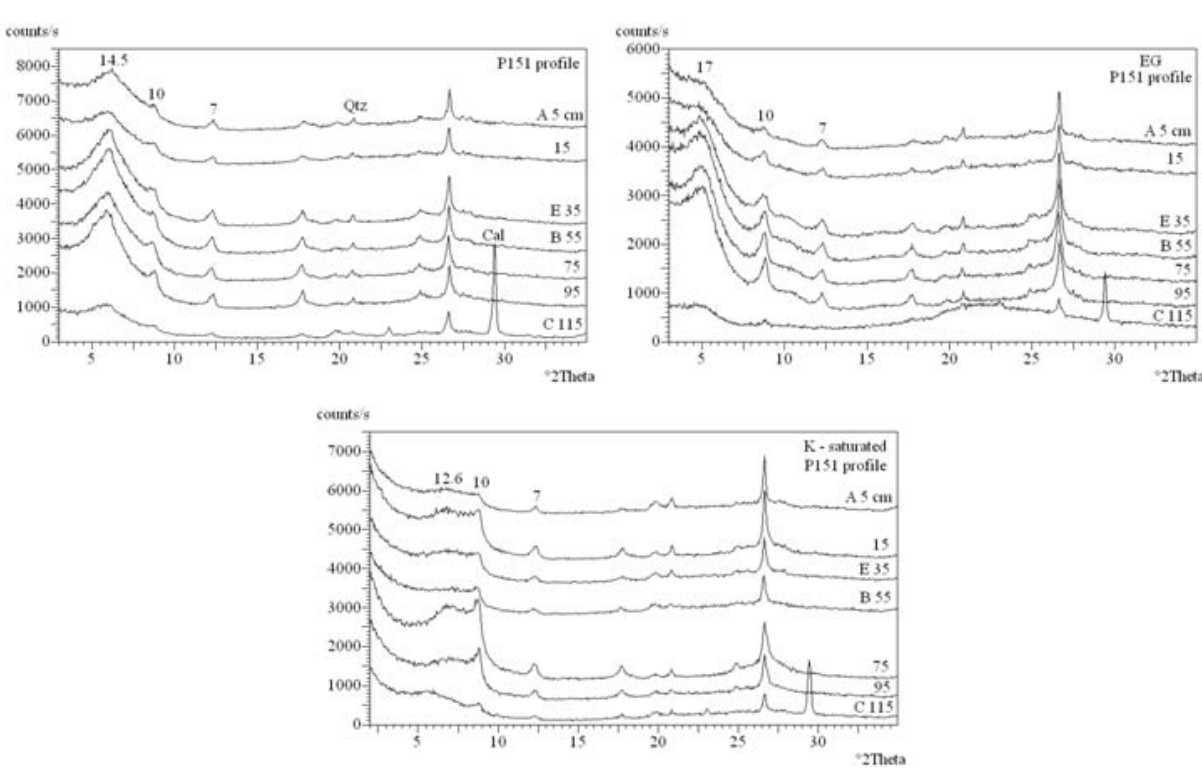

Fig. 4

XRD patterns of the clay fractions in the genetic horizons of Profile P151 after the diagnostic treatments

tensity of the $10 \AA$ peak as compared to the $7 \AA$ peak of kaolinite clearly indicates the decrease in illite content upwards. In the case of ethylene-glycol solvation the $17 \AA$ reflection attributed to smectite became less pronounced in the $\mathrm{E}$ and mainly in the A horizon. Based on the $\mathrm{v} / \mathrm{p}$ (valley to peak) ratio (BISCAYE, 1965) after glycolation the crystallinity of smectite decreases from the bottom of the B horizon to the A horizon, indicating smectite degradation during weathering. In addition, the position of the second order peak shifted gradually from $8.50 \AA$ to around $8.90 \AA$ upwards in the profile, indicating the presence of illite/smectite mixed layers, with theoretically pure smectite at $95 \mathrm{~cm}$, about $15 \%$ illite in $\mathrm{I} / \mathrm{S}$ at $55 \mathrm{~cm}$ (top of the B horizon), $30 \%$ in the E, and finally $40 \%$ illite in the A horizon. The $10 \AA$ peak increased markedly due to $\mathrm{K}$ saturation at the bottom of the profile, while in the $\mathrm{B}$ (55 $\mathrm{cm}), \mathrm{E}$ and A horizons the shifting of the smectite basal peak to $12.5 \AA$ is evidenced, demonstrating the presence of high charged layers at the bottom and that of low charged ones at the top of the profile. Based on these XRD features, the most possible pathway of clay alteration is illite smectitization via charge reduction, and considerable degradation of smectite. On the contrary, a further illitization process from the top of the profile is also mentioned as a possibility.

A high abundance of calcite occurs in the clay fraction of the $\mathrm{C}$ horizon. It evokes the contribution of pedogenic carbonates leached from the A and B horizons to inherited ones (SIMON et al., 1999). 


\section{Profile P161}

The mineral composition of the bulk soil is dominated by quartz. Its amount diminishes from $80 \%$ in the A horizon to $60 \%$ in the $\mathrm{C}$ horizon. At the same time the amount of feldspars (mainly plagioclase) increases considerably in the $\mathrm{C}$ horizon $(25 \%)$, indicating that it was inherited from the andesite parent rock. The proportion of phyllosilicate clay minerals is $20-25 \%$ in horizons B and C, while it is only $10 \%$ in the A horizon.

The peaks at 7 and $3.58 \AA$ Á refer to kaolinite, at $10 \AA$ to illite, but the major clay mineral phase is represented by the $14.5 \AA$ peak (Fig. 5). The illite and kaolinite content tend to decrease slightly downwards. The $14.5 \AA$ peak shifted to $17 \AA$ after glycolyzation, but similarly to Profile P151, the crystallinity becomes poorer upwards in the profile. Following Mg saturation and glycerol solvation at $14.2 \AA$ a shoulder appeared next to the $18 \AA$ peak, indicating the presence of partly and fully expansible layers (smectite), respectively. After K saturation the $14.2 \AA \mathrm{Mg}$ saturated and glycerol solvated phase collapsed to $10 \AA$, allowing this phase to be identified as vermiculite. Vermiculite becomes the major phase instead of smectite from the $65 \mathrm{~cm}$ depth (top of the B horizon) upwards, in the $\mathrm{E}$ and A horizons. On the contrary, K saturation revealed the dominance of low layer charged smectite in the $\mathrm{C}$ horizon, suggesting its formation from feldspars and volcanic glass of the andesite bedrock (THOREZ, 1976). On the basis of the Green-Kelly test, the smectite is montmorillonite. The main process is vermiculite formation, most probably by the conversion of low charged smectite to high charged vermiculite.
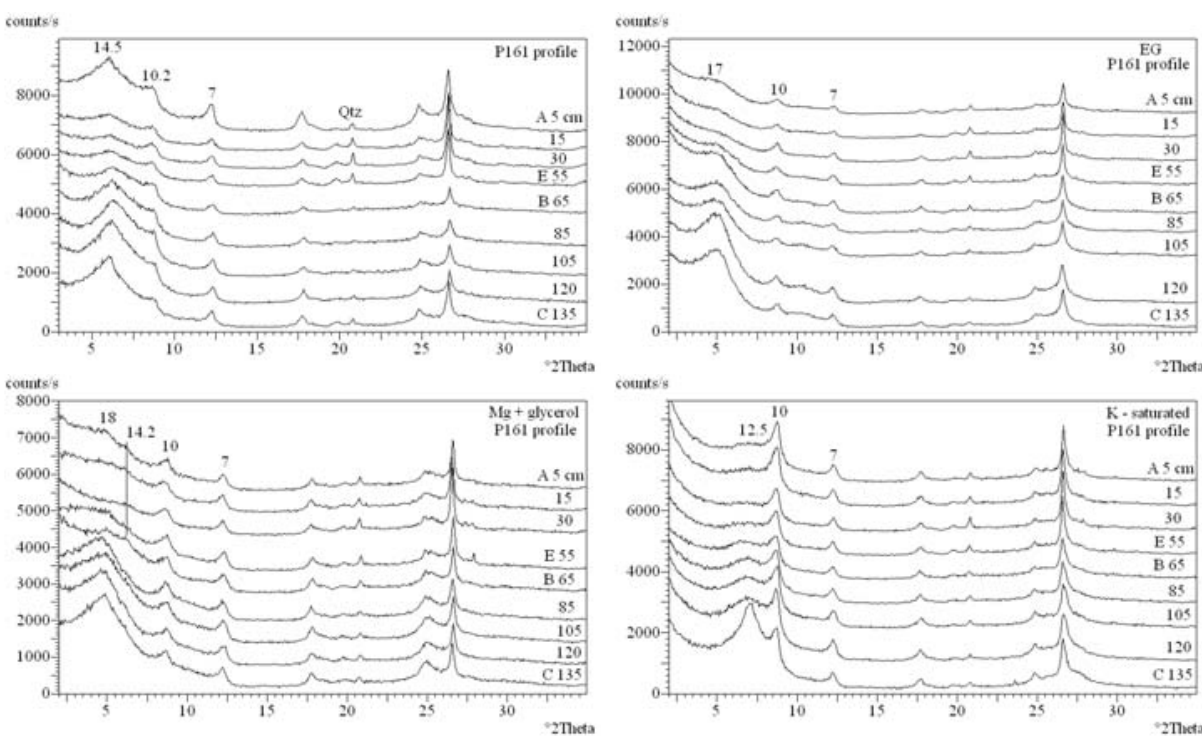

Fig. 5

XRD patterns of the clay fractions in the genetic horizons of Profile P161 after the diagnostic treatments 


\section{Conclusions}

Brown forest soils (Luvisols) formed on various parent rocks show differences in the details of their clay mineralogy and consequently are characterized by different clay mineral alteration processes. A common feature in all four studied soil profiles is that swelling clay minerals predominate in them. Similar siltstone bedrock weathered to chlorite/vermiculite and vermiculite in a less developed shallow soil profile (P09) with considerable calcite content. The major product of soil formation in a clayey, well developed deep soil (P131) is a typical soil montmorillonite with heterogeneous charge distribution. Based on these findings, the suggestion of APRIL et al. (1986) - that the occurrence of vermiculite in soils does not depend primarily on the nature of the parent rock - apparently holds true for the soils of the Cserhát Mountain region. The characteristic clay minerals in the soil formed on limestone (Profile P151) are smectite and illite/smectite with evident charge reduction and degradation of illite and smectite during weathering. In this profile the illite/smectite interstratification seems to be the consequence of a polyphase process, even including reaction pathways with opposite directions. On the contrary, weathering of andesite parent rock (P161) involves the formation of low charged smectite altering to high charged vermiculite during pedogenesis.

\section{Summary}

The clay mineral composition of four brown forest soil profiles (Luvisols) developed on different parent rocks was studied in detail to determine the major clay mineral alteration processes. In the studied profiles a siltstone bedrock weathered to chlorite/vermiculite and vermiculite in a less developed, shallow soil profile, while the major product of soil formation in a clayey, well-developed deep soil is a typical soil montmorillonite with heterogeneous charge distribution. The most possible pathway of clay alteration is illite smectitization via charge reduction, and considerable degradation of smectite in the soil formed on limestone. On the contrary, weathering of andesite parent rock involves the formation of low charged smectite altering to high charged vermiculite during pedogenesis.

Key words: clay minerals, forest soil, Luvisols, vermiculite, smectite

\section{References}

April, R. H., Hluchy, M. M. \& Newton, R. M., 1986. The nature of vermiculite in Adirondack soils and till. Clays and Clay Minerals. 34. 549-556.

BADRAOUI, M. \& BLOOM, P. R., 1990. Iron-rich high charge beidellite in Vertisols and Mollisols of the High Chaouia region of Morocco. Soil Sci. Soc. Am. J. 54. 267 274. 
BISCAYE, P. E., 1965. Mineralogy and sedimentation of recent deep-sea clay in the Atlantic Ocean and adjacent seas and oceans. Geological Society of America Bulletin. 76. 803-832.

GreEN-Kelly, R., 1953. The identification of montmorillonoids in clays. J. Soil Sci. 4. 233-237.

LAGALY, G., 1994. Layer charge determination by alkylammonium ions. In: Layer Charge Characteristics of 2:1 Silicate Clay Minerals. (Ed.: MERmuT, A. R.) CMS Workshop Lectures. 6. 1-47. The Clay Minerals Society. Boulder.

Lagaly, G., Fernandez GonZalez, M. \& Weiss, A., 1976. Problems in layer-charge determination of montmorillonites. Clay Minerals. 11. 173-187.

LiM, G. H. \& JACKSON, M. L., 1986. Expandable phyllosilicate reactions with lithium on heating. Clays and Clay Minerals. 34. 346-353.

RÉDLY, L.-NÉ, 1988. Determination of the cation exchange capacity of soils by the modified Mehlich method. In: Manual of Soil and Agrochemical Analysis. (Ed.: BuZÁs, I.) II. (In Hungarian) 116-117. Mezőgazda Kiadó. Budapest.

Righi, D., Terribile, F. \& Petit, S., 1998. Pedogenic formation of high-charge beidellite in a Vertisol of Sardinia (Italy). Clays and Clay Minerals. 46. 167-177.

SimON, B. et al., 1999. $\mathrm{CaCO}_{3}$ eluviation and precipitation processes in paleosols. In: Proc. $2^{\text {nd }}$ Intern. Conf. of PhD Students. 49-53. University of Miskolc. Miskolc.

SimON, B. et al., 2002. Factors affecting soil acidity in Hungary. Agrokémia és Talajtan. 51. 53-62.

SIPOS, P., 2003. Distribution of $\mathrm{Cu}, \mathrm{Ni}, \mathrm{Pb}$ and $\mathrm{Zn}$ in natural brown forest soil profiles from Cserhát Mts., NE Hungary. Acta Mineralogica-Petrographica. 44. 43-50.

SIPOS, P., 2004. Geologic and pedogenic effects on heavy metal distributions in forest soils from the Cserhát Mts and the Karancs area, NE Hungary. Acta Geologica Hungarica. 47. 411-429.

Sipos, P., NÉmeth, T. \& MOHAI, I., 2005. Distribution and possible immobilization of lead in a forest soil (Luvisol) profile. Environmental Geochemistry and Health. 27. $1-10$.

StefanOVITS, P., 1971. Brown Forest Soils of Hungary. Akadémiai Kiadó. Budapest.

SzEGI, T. et al., 2004. Rheological investigations on the aggregate stability of cultivated Calcic Chernozems. (In Hungarian) Agrokémia és Talajtan. 53. 239-250.

TERrito, C. et al., 2005. A new simple approach to evaluate pedogenic clay transformation in a Vertic Calcisol. Journal of Geochemical Exploration. 88. 345-349.

THOREZ, J., 1976. Practical Identification of Clay Minerals. G. Lelotte. Dison. Belgium. 